\title{
Verdensmålene: En vision for verden
}

\author{
Af Steen Hildebrandt *)
}

Verdensmål. Verdens mål. Mål for verden! Kan man forestille sig noget større eller mere revolutionerende, udfordrende, respektindgydende og håbefuldt? Menneskehedens, homo sapiens' historie spænder over ca. 300.000 år. Planeten Jordens historie går 4,5 milliarder år tilbage. Der har været liv på Jorden i 3,8 milliarder år. Fem gange i disse milliarder år har der været såkaldte masseuddøener, dvs. perioder, hvor meget store dele af alt liv på Jorden døde. Sidste gang - den femte masseuddøen - var for ca. 66 millioner år siden, og her antages det, at ca. 75 pct. af alt liv på Jorden blev udslettet. Spørger man på Københavns Universitet eller på andre universiteter rundt om i verden, vil man få at vide, at vi lige nu befinder os i begyndelsen af den sjette masseuddøen. Vi skal omgås dette ord med forsigtighed, men vi skal ikke lukke vore øjne for, at der sker alvorlige begivenheder på planeten jorden, og at nogle af disse begivenheder og fænomener er skabt af mennesker. De er forårsaget af menneskelig aktivitet. Carsten Rahbek, professor ved Center for Makroøkologi, Evolution og Klima ved Københavns Universitet, siger: ”Dyre-og plantearter indgår i et komplekst økosystem med hinanden det sted, hvor de lever. Fjerner man enkelte arter, bliver systemet ustabilt. På et tidspunkt kollapser det. Vi ved ikke nok om, hvad der præcist skal til, for at et økosystem kollapser, men vi ved, at vi leger med ilden i øjeblikket”.

*) Steen Hildebrandt er ph.d. og professor emeritus ved Aarhus Universitet og adjungeret professor ved CBS og Aalborg Universitet. 
Et opsamlingsstudie af den nyeste viden på området publiceret i tidsskriftet Science viser, at den sjette masseuddøen ikke er en dyster periode, der måske ligger forude. Vi gennemgår den tvært imod lige nu. ”Det er ikke længere et spørgsmål om, hvorvidt en ny masseuddøen indtræffer. Vi er midt i den. Nu er spørgsmålet i stedet, hvor hurtigt arterne vil uddø, og hvilke konsekvenser det får for økosystemerne og os selv”, siger Carsten Rahbek. Professor Jens-Christian Svenning fra Institut for Bioscience ved Aarhus Universitet siger: "Når vi ser på, hvor mange arter der er i kraftig tilbagegang og dermed alvorligt truet af uddøen, bliver det klart, at vi befinder os i det tidlige stadie af den sjette masseuddøen” (Her citeret fra: Videnskab.dk).

\section{A. Baggrund og udfordringer}

\section{Krise og muligheder}

Man kan spørge lige ud: Kommer alt dette mig ved? Mange afviser denne tale om både naturkatastrofer og menneskeskabte katastrofer og begivenheder, herunder den nævnte masseuddøen, som dommedagstale. Det er vildt overdrevet, lyder et af argumenterne; vi taler om århundreder, årtusinder - og endnu mere? Hvordan skal det enkelte menneske kunne forholde sig til alt dette? Vi, der lever lige nu - hvad kommer dette os ved? Man må stille sig disse spørgsmål, og det er naturligvis legitimt at melde hus forbi og erklære sig uinteresseret i sådanne store og vanskelige spørgsmål. Det gør mange mennesker. Andre afviser selve indholdet i nogle af disse mange påstande om Jordens situation og om de trusler og faresignaler, der tales om. Det er også legitimt. Det er opspind, det er smarte forretningsinteresser og lobbyister, der tegner alle disse skrækscenarier - hævdes det blandt andet. Eller med et moderne udtryk: Det er fake news.

Ja, spørgsmålet er, hvad der er fake, og hvad der er sandt? Og her må det erkendes og understreges: Mange af de fænomener, hvorom der her er tale, er der ikke fuldstændig enighed om i faglige og videnskabelige kredse og ej heller i politiske partier og andre grupperinger. Hertil kommer, at mange mennesker, uanset uddannelse og baggrund, ikke kan gennemskue disse komplicerede fænomener. De må derfor henholde sig til, hvad og hvem de tror på. Tro og tillid er vigtige aspekter her. Men uanset alt dette, så er der - tilsyneladende - en voksende gruppe mennesker verden over, som mener og hævder, at vi, der lever nu, har en viden om og en tro vedrørende verdens situation, der forpligter os til at handle - og handle nu. Og det er det, vi må forholde os til. 
Vi ved, at de sidste ét hundrede år har budt på en økonomisk, materiel, demografisk, geologisk, biosfærisk og atmosfærisk udvikling, der - på godt og ondt - og på nogle måder er uden sidestykke i Jordens historie, og som har påvirket selve jorden, naturen, dyrene og menneskene så meget, at alvorlige trusler ser ud til at være realiteter. Vi taler om den store acceleration, om den antropocæne epoke, om bæredygtighedens periode, om den sjette masseuddøen mm. Der ser ud til at være, hvad man må kalde evidens for, at jordens situation, menneskehedens situation, biodiversiteten på Jorden er så truet, at muligheden for egentlige katastrofer ikke kan afvises, ja, at katastrofer måske er nært forestående, medmindre verdens borgere, regeringer, virksomheder mm ændrer adfærd på en række områder. Eller sagt på en anden - og mere populær, men alligevel klar og brugbar måde: Business as usual er ikke en mulighed. Vi siger det undertiden på den måde, at "Today's problems come from yesterday's solutions", og i det ligger også den gamle indsigt, at et problem ikke kan beskrives og løses med den tænkning, der har skabt det. Der er behov for nytænkning, nye veje.

Man kan også anlægge helt andre betragtninger. Uanset hvorledes man forholder sig til trusler og risikovurderinger, kan man kaste et blik på verdens aktuelle situation belyst ved billeder, analyser, beskrivelser, statistisk materiale fra enkeltlande, FN, Verdensbanken, OECD mm. Gør man det, vil man bl.a. kunne se, hvor stor uligheden i verden er, hvor stor fattigdommen i verden er, hvor mange mennesker, der sulter, tørster, mangler medicin, ingen uddannelse får, etc. Sammenholder man dette med de ressourcer, viden, teknologi, uddannelser, som vi, menneskeheden, har, så er det uden for diskussion, at det er muligt at forbedre livet og livsmulighederne for millioner af mennesker verden over, uden at det nævneværdigt vil gå ud over de mennesker, der ikke lider nød, men som lige nu har tilstrækkeligt af alt. Alt på kloden er ufatteligt skævt fordelt. Vil mennesker være med til at forbedre livskvaliteten og livsmulighederne for andre mennesker, der i øjeblikket lider og lider afsavn i forhold til mange andre mennesker på Jorden? Det er ét af de helt store spørgsmål, som alle mennesker bør forholde sig til.

\section{Menneskers motiver og handlinger}

Så længe, det er juridisk acceptabelt og økonomisk (pengemæssigt) fordelagtigt for mennesker at producere og sælge ikke-bæredygtige produkter og ydelser, vil der finde en ikke-bæredygtig produktion sted i verden. I mange tilfælde får de økonomiske motiver og argumenter oven i købet lov til at dominere over og udmanøvrere lovgivning, regler, aftaler og andet juridisk, og så begås 
der i realiteten aftalebrud, lovbrud, kriminalitet mm. med det formål at gennemføre økonomisk fordelagtige ikke-bæredygtige (og bæredygtige) aktiviteter. Vi må antage - eller rettere: vi véd, at dette finder sted i meget stort omfang overalt i verden. Der er utallige eksempler: Skatteunddragelse er ét eksempel på sådanne ikke-bæredygtige aktiviteter og fænomener. Lovgivning alene er ikke tilstrækkelig til at forhindre ikke-bæredygtig adfærd og handling. Man kan ikke lovgive sig til bæredygtighed.

Jura, økonomi, etik og moral er blandt de faktorer, der er afgørende for menneskers handlinger. Verdensmålene indeholder alle disse aspekter. Landene har forpligtet sig til at udarbejde planer og rapporter vedrørende deres arbejde med verdensmålene. Men det er meget vagt formulerede forpligtelser, og der er ingen strafforanstaltninger knyttet til en manglende overholdelse af bestemmelserne. Verdensmålene indeholder en lang række etisk-moralske tilkendegivelser, som individer, organisationer og lande kan vælge at forholde sig positivt til og aktivt arbejde for at realisere. Men alle kan også vælge det modsatte: At ignorere eller direkte modarbejde verdensmålene. Der er knyttet umådeligt store økonomiske konsekvenser, interesser og muligheder til verdensmålene, men det er op til milliarder af selvstændige økonomiske enheder på egen hånd at tage stilling til, hvilken indsats de hver især vil yde i forhold til verdensmålene, herunder vælge intet at gøre.

\section{Verdensmålene er skrøbelige.}

Mange af de ubalancer, udfordringer, problemer mm., som verdensmålene er skabt for at angribe, udbedre og løse, er skabt af mennesker, er forårsaget af menneskers motiver og aktiviteter. Verdensmålene er udtænkt af, formuleret og skabt af mennesker. Menneskeheden står med gigantiske udfordringer - og med tilsvarende gigantiske muligheder. Det er op til os mennesker at begribe og gribe disse udfordringer og muligheder. Verdensmålenes realisering er et menneskeligt anliggende. Det er ikke en acceptabel forklaring eller undskyldning, at mennesker er styret af kortsigtede og egoistiske økonomiske interesser og motiver, og at al den destruktion og alt det negative, der finder sted i verden på grund af menneskers adfærd, derfor er naturlig. Det er ikke naturligt. Det er unaturligt. Det er imod naturen.

Alt dette er en del af baggrunden for, at en betydelig del af de aktiviteter og den produktion, der i dag finder sted i millioner af virksomheder verden over, er ikke-bæredygtig. For at forstå, hvorledes det går til, skal man som berørt oven for forstå, hvorledes der træffes beslutninger i 
virksomheder, organisationer, husholdninger og lande. Det er i vid udstrækning i virksomhederne, at de beslutninger træffes, der er afgørende for, i hvilket omfang og i hvilket tempo bæredygtig adfærd fremmes eller ikke fremmes. De politiske beslutninger på alle niveauer, fra lokalt, over nationalt og op til overstatsligt niveau, er afgørende for de rammer og vilkår, som virksomhederne (og husholdningerne) agerer inden for og må respektere, men det er i selve de private virksomheder, at det konkret og i vid udstrækning afgøres, hvilken udvikling der finder sted i verden på bæredygtighedsområdet. Det er nemlig her, alle indkøbs-, produktions-, salgs- og andre beslutninger træffes. Det hører selvsagt med til billedet, at dette sker i et meget kompliceret samspil med de millioner af forbrugere verden over, der er i kontakt med virksomhederne i alle de transaktioner, der finder sted på markederne, og som tilsammen afgør den industrielleøkonomiske udvikling.

\section{Den ledelsesmæssige baggrund}

De fleste strategiske ledelsesprocesser indeholder nogle bestemte elementer. For det forste en beskrivelse og vurdering af den situation, som den pågældende organisation befinder sig i eller er karakteriseret ved i udgangssituationen. Vi kaldet det en situationsbeskrivelse.

For det andet en beskrivelse af, hvor organisationen vil hen, hvad den vil opnå, hvilke mål og visioner, den har for sin eksistens og videre udvikling. En mål- og visionsbeskrivelse. Begge disse beskrivelser kan være meget detaljerede, herunder flerdimensionelle, og der er begribeligvis en sammenhæng mellem kvaliteten af disse beskrivelser eller formuleringer og det eller de resultater, der kan opnås gennem den strategiske proces, der er sigtepunktet med bestræbelserne.

Går man videre, vil den strategiske proces for det tredje indeholde beskrivelser og analyser af den historie, de begivenheder og beslutninger i fortiden, der har ført organisationen frem til den nuværende situation. En biografisk-historisk beskrivelse.

Og endelig, for det fjerde, vil det strategiske arbejde indeholde mere eller mindre omfattende beskrivelser og analyser af de omgivelser, hvori organisationen befinder sig, og som den dermed selv er en del af, dvs. en omverdensbeskrivelse. Og endelig er det femte element i afgrænsningen af organisationens handlingsrum den nationale og internationale lovgivning og de aftalesystemer, som organisationen er undergivet og part i, og som den derfor må leve op til. En juridiskinstitutionel dimension. 


\section{Et strategisk handlingsrum}

Tilsammen fører en sådan strategisk ledelsesproces frem til en indkredsning af et handlingsrum, et handlingsmulighedsrum for organisationen, inden for hvilket det er muligt at operere og træffe både strategiske og operationelle beslutninger. Lad os kalde det virksomhedens strategiske råderum. Afgrænsningen af dette råde- eller handlingsrum og de kriterier og den lovgivning, ud fra hvilke virksomhederne træffer deres beslutninger, er selvsagt afgørende for, hvilke konkrete beslutninger virksomhederne træffer. Holdningen og forståelsen har hidtil i langt de fleste lande i verden været, at enhver virksomhed kan udfylde dette rum på lige netop den måde, som virksomheden finder er bedst for den - altid under den forudsætning, at gældende love og aftaler overholdes. Vi taler om et liberalt syn på den private virksomhed og dens muligheder og opgaver, og dette syn har i praksis været karakteriseret ved åbne og frie markeder i store dele af verden, hvor virksomheder har udbudt produkter og ydelser, som et marked dernæst har efterspurgt, eller omvendt: et marked har efterspurgt ydelser og produkter, som private virksomheder herefter har svaret på ved at producere og levere det efterspurgte til markedet, og på baggrund af denne såkaldt frie prisdannelse bliver og er milliarder af handler eller transaktioner blevet indgået. Vi taler om frie markeder, om fri prisdannelse, om en fri markedsøkonomi. Inden for lovens rammer har virksomhederne kunnet agere, og de har og har haft meget vide rammer for, hvad de vil udvikle, producere, markedsføre og sælge. Om de vil sælge usund, måske sundhedsfarlig mad eller $\varnothing$ kologisk, sunde og bæredygtigt producerede fødevarer, var op til virksomhedernes ledelser. Hvis de ville udvikle og producere våben til børn, var det i visse lande op til dem. Om de ville udvikle kemikalier, hvis virkninger for mennesker og dyr, man ikke havde nogen sikker - om nogen viden om, var op til virksomhederne. Op gennem 1900-tallet blev der på den måde udviklet ca. 100.000 nye kemikalier i EU, hvis virkninger, man ikke havde og ikke har nogen sikker viden om. Tænkningen er, at alt er tilladt, indtil det er bevist, at det er skadeligt for mennesker og dyr. Det siger sig selv, at hvis millioner af virksomheder verden over hver dag på den måde træffer globalt set uhensigtsmæssige beslutninger, så lider kloden derved. En række problemer akkumuleres i kølvandet på en sådan globalt set uhensigtsmæssig strategisk adfærd fra de private virksomheders side.

\section{Lovgivning sikrer ikke bæredygtighed}

Det siger sig selv, at hvis det er tilladt og fordelagtigt og hvis landenes skatte- og afgiftsbestemmelser der ud over måske ligefrem fremmer en ikke-bæredygtig adfærd og produktion, så får verden ikke-bæredygtige virksomheder og produkter. Det er præcist, hvad der i 
vid udstrækning i dag er tilfældet og resultatet. Megen lovgivning verden over ansporer virksomheder til ikke-bæredygtig adfærd. Megen efterspørgsel fra forbrugere verden over fremmer ikke-bæredygtig produktion. Mange interesseorganisationer og tusindvis af lobbyister verden over arbejder hver dag systematisk og ensidigt for at fastholde og udbygge ikkebæredygtig produktion og adfærd. Og på første række med rådgivere og eksperter sidder økonomerne og ude i periferien står fysikere, kemikere, pædagoger, psykologer, sundheds- og ernæringseksperter og mange andre slags eksperter og advarer; verden er fyldt med udredninger og analyser, der klargør og dokumenterer, hvor skadelig denne adfærd fra virksomhedernes side er, og vi har samtidig tilgængelig viden, der viser, hvorledes vi kan dreje verdens udvikling i en anden retning. Det seneste og stærkeste, verden har i den sammenhæng, er verdensmålene. Det skal føjes til - som en selvfølge: Der er også virksomheder i verden, der er klart fokuserede på at producere bæredygtigt og på i den forbindelse at arbejde bevidst for FN’s 17 verdensmål. Der er mange af den slags virksomheder. Og formentlig er det rigtigt at sige: Hvor det for 10 år siden var naivt bare at tale om bæredygtighed i erhvervskredse, så er det i dag naivt ikke at tale om bæredygtighed. Ikke-bæredygtig adfærd er taberadfærd.

\section{Hvem bestemmer, hvad bæredygtighed er}

Oven for er der talt om strategiske processer i private virksomheder, men det kan også handle om en strategisk proces i en kommune, et land og EU, eller det kan handle om fx G-20 landene. Hvem bestemmer, hvorledes disse landes og deres fælles situations- og målbeskrivelser skal se ud, og hvad de skal indeholde? Hvem skal tage stilling til, hvilke beskrivelses-dimensioner og målemetoder, der skal benyttes? Hvornår handler det om subjektive, såkaldt politiske vurderinger og spørgsmål, og hvornår handler det om ekspert-udsagn og ekspertviden? Hvem bestemmer, hvem der er ekspert, og hvem der ikke er? Hvem bestemmer, hvad ekspertviden er? Hvem rådgiver og hvem lytter - og hvem rådgiver rådgiverne?

Til G20 topmødet i Hamburg i 2017 var der udkommanderet mere end 20.000 politibetjente for at skabe ro og på den måde hjælpe med til at finde svarene på nogle af disse mange spørgsmål. Det er nemlig ikke så let og ligetil, som det kan se ud til. Dels er landene indbyrdes meget uenige, og i særlig grad er der uenighed mellem de politiske ledere og store grupper af mennesker i de lande, det handler om, konkret eksemplificeret ved måske 100.000 borgere i Hamburg. En overskrift i dagbladet Politiken lød: ”Når verdens rigeste mødes, pisser de på de fattigste”. Mange store spørgsmål er på spil, både eksplicit og mere ubevidst og skjult: Er den rigtige mål- og 
måledimension penge og økonomisk vækst, eller er det klimaet og den globale opvarmning, der skal være i centrum? Er det økonomisk vækst for de mennesker, der i forvejen har en solid økonomi, eller er det vækst for de fattigste mennesker i landene? Og midt i alt dette også spørgsmålet: Skal man give en stemme til de endnu ikke fødte mennesker og betragte dem som relevante interessenter?

G20 landenes ledere betegnes i medierne som de mest magtfulde mennesker i verden. De repræsenterer lige nu ca. 85 pct. af verdens økonomi. Men kunne man også kalde dem de største forbrydere i verden? Hvis det er sandt, at de er så magtfulde, som de officielle beskrivelser indikerer, så har de også et stort medansvar for alle de fortrædeligheder, der finder sted i verden, fx at flere hundrede millioner mennesker sulter, at børn dør af de mest simple og helbredelige sygdomme, at dyrearter udryddes, at millioner af mennesker dør på arbejdspladser på grund af dårligt fysisk og psykisk arbejdsmiljø, osv. Hvis disse ledere begår en synlig økonomisk forbrydelse, bliver de øjeblikkeligt straffet og frataget deres embede - i hvert fald i åbne demokratiske lande. Men hvad med alle de andre handlinger eller forbrydelser, som de begår og medvirker til? Hvorfor bliver de politiske ledere ikke straffet, der er medansvarlige for en kultur, en lovgivning og en praktiseret forvaltning, der medvirker til, at kvinder bliver udsat for vold og mishandling, at børn lider af dårlig ernæring, der gør, at de får livsvarige skader, at narkotika og andre stoffer produceres, handles og giver anledning til mord og forbrydelser verden over? Medvirker til, at det er tilladt at udvikle, producere, markedsføre og sælge de mest skadelige og livsfarlige produkter, fx skydevåben og særlige skydevåben til børn i USA? Hvorfor, hvorfor?

\section{B. Hvem er ansvarlige for de aktuelle ledelsesforhold}

\section{A. Økonomer i første række}

De, der sidder på første række og har størst autoritet, når der skal gives råd, hvad enten det er i G20-sammenhæng, i Verdensbanken, OECD, EU eller i enkeltstater eller virksomheder, er utvivlsomt økonomer. Som Kate Raworth siger i sin bog, Doughnut Economics: Økonomi er det offentlige livs og den offentlige sektors og politiks forståelsesramme, og det er den, der former de moderne samfund. Selv i disse første årtier af det 21. århundrede er det økonomiske antagelser, værdier og trossætninger, der bestemmer, hvad og hvordan vi tænker, føler, beslutter og gør. Det har vidtrækkende konsekvenser, at økonomer er de eksperter, der lyttes mest til. For økonomer ser verden med de dominerende økonomiske teoriers begrebsverden, og denne begrebsverden gør 
alt op i penge. Til denne begrebsverden hører ikke barnets eller kvindens skrig, sygdom, sult og lidelser; økonomer måler ikke dyrenes lidelser og udryddelse, måler ikke en række af de ofre, der er forbundet med det moderne erhvervslivs høje produktivitet. Og intet kan være de økonomiske modeller mere ligegyldigt, end den globale ressource- og klimasituation for ikke at tale om de fremtidige generationer. Tvært imod udarbejder og benytter lande og virksomheder fortsat kalkuler og regnskaber, der kun indeholder en del af de omkostninger og ofre, der er forbundet med at producere de varer og gennemføre de aktiviteter, der er virksomhedernes og samfundenes opgaver og felt. En lang række omkostninger eller ofre, forbundet med den aktuelle produktion og aktivitet, blev og bliver på den måde ikke medegnet i virksomhedernes og landenes regnskaber. Man taler i den sammenhæng bl.a. om eksternaliteter; det gælder fx det $\mathrm{CO} 2$ udslip, der er en følge af virksomhedens aktiviteter. Konsekvensen er bl.a. den meget klare at der overalt i verden bliver truffet milliarder af beslutninger, der ville være helt anderledes, såfremt de blev baseret på mere retvisende kalkuler.

Klassiske økonomer og klassiske ledelsesteoretikere er blevet forenet i en forståelse af, at mennesket kan og skal tage magten over naturen. Det er en forståelse af, at naturen er menneskets redskab og middel, som vi mennesker kan bruge til hvad som helst. Til at underbygge og formidle denne forståelse har økonomer og ledelsesforskere opbygget en række simple og urealistiske modeller og teorier. Resultatet er, at vi driver rovdrift på naturen, og der er næsten ingen grænser for, på hvilke områder mennesker tror, at de kan intervenere i naturens processer og sammenhænge - alene ud fra kortsigtede økonomiske betragtninger.

Ordet økonomi kommer af de græske ord oikos og nomos, der betyder henholdsvis husholdning og normer, altså normer eller regler for husholdning. I de mellemliggende mange år har vi glemt, at økonomi dybest set handler om at holde ordentligt hus med det hele, med hele huset. I virkeligheden peger det frem mod det, som vi i dag vil kalde planetarisk husholdning og planetarisk lederskab eller forvalterskab. Det handler om alle ressourcer og om alle familiemedlemmer, hvoraf der lige nu er knap 7 1 $\frac{1}{2}$ milliard. Det handler om kloden. Men i stedet for at holde hus ødelægger vi faktisk huset. Eksemplerne fylder bøger. Ca 40 pct. af klodens landbrugsareal er alvorligt nedbrudt og udpint; i 2025 vil to ud af tre mennesker i verden leve i områder, hvor der er mangel på vand, såkaldt vandstressede områder. Mere end 80 pct. af alle have er nu fuldt udnyttet eller overudnyttet med hensyn til fiskeri. Mængden af plastikaffald i 
verdenshavene stiger, og i 2050 vil der med den nuværende vækst være mere plastik end fisk i havene.

Det økonomiske og ledelsesmæssige sprog dominerer på alle områder af samfundslivet. Værdien af alt opgøres i penge. Vort sprog og vores forståelse er, at skoler, universiteter, kulturinstitutioner som fx teatre og museer, hospitaler og andre offentlige virksomheder skal levere ydelser, der skal kunne betale sig. De skal producere til konkurrencedygtige priser og omkostninger, og kan de ikke det, skal de konkurrenceudsattes, privatiseres eller nedlægges. Alt handler om økonomi, hvilket i den offentlige forvaltning fører til, at det er finansministerierne, der bestemmer. Den offentlige politiske debat er præget af et vulgært, indforstået, ofte uforståeligt, økonomisk fagsprog med en række fagudtryk og indforståede sammenhænge. Ofte har man det indtryk, at de, der taler dette sprog, ikke selv forstår, hvad de siger. Og ofte må man undres over, hvor primitivt økonomer taler.

Selvfølgelig er der behov for økonomer; der er ingen tvivl om, at økonomer har haft en stor og positiv betydning for udviklingen af de velfærdssamfund, som vi kender rundt om i verden, nok mest markant i de skandinaviske lande. Men alligevel er det svært at forstå, at politikere og økonomer verden over hårdnakket holder fast i en økonomi- og væksttænkning, der samlet set er destruktiv og er ved at smadre forudsætningerne for fortsat liv på kloden. Det er ubegribeligt, at økonomer og politikere ikke vil lytte til alle de advarsler, der fremføres af de mest forskellige og mest kompetente forskere og fagmennesker verden over. Advarsler, som nu er så alvorlige og massive, at vi alle kan forstå dem. Nogle af dem kan vi endda erfare med vore egne øjne. Eksperter af mange slags står på sidelinjen og råber; befolkningerne råber og demonstrerer. Men økonomerne og deres alt for snævre og ensidige modeller og begreber får fortsat lov til at dominere.

I den nævnte bog tegner Kate Raworth et billede af menneskehedens udvikling, der op gennem det 21. århundrede vil blive ledet af politikere og embedsmænd, lærere, journalister, kommunale ledere og vælgere, der i øjeblikket bliver undervist rundt omkring på fagskoler og universiteter. Og disse mennesker, der vil være aktive borgere i 2050, undervises lige nu i en økonomisk tankegang, som har sine rødder i lærebøger fra 1950, lærebøger, som igen har sine rødder i teorier fra 1850. Hvis man tager i betragtning, hvor hurtigt alting ændrer sig i det 21 . århundrede, så tegner dette til at blive en katastrofe, siger hun. Selvfølgelig er dette en forenkling, men betragt 
den politisk-økonomiske debat, analysér det beslutningsgrundlag og den lovgivning, der aktuelt finder anvendelse rundt omkring i verdens lande, og man vil finde, at Raworth beskriver situationen ret præcist.

Kate Raworth taler om økonomers underlige, snævre og urealistiske antagelser om virkeligheden og på den baggrund tegner hun konturerne af en strategisk tænkning for det 21 . århundrede, der bl.a. indeholder en ny forståelse af økonomi og af økonomers rolle i samfundsudviklingen. Hun stiller det meget enkle spørgsmål: Hvad med at indlede økonomistudiet, ikke med at betragte alle de gamle og veletablerede teorier, men med at betragte menneskehedens langsigtede behov og mål og ud fra det udvikle den økonomiske tænkning, der vil gøre det muligt for menneskeheden at nå disse mål? Med økonomiske begreber som baggrund taler hun i virkeligheden om en ny strategisk ledelsesforståelse for lande eller grupper af lande.

Denne tænkning førte for Raworth frem til en model, der ligner en doughnut, den velkendte amerikanske kage med et hul i midten, og hvis hovedindhold er: 1) Et socialt fundament bestående af social lighed, ligestilling, demokratiske rettigheder, fred og retfærdighed, uddannelse, sundhed, føde og vand, energi, menneskelige relationer og boligforhold, 2) Et økologisk loft, der bl.a. indeholder og handler om klima, luftforurening, biodiversitet, landudnyttelse, rent vand, kemisk forurening, og 3) Et råderum, et sikkert og retfærdigt rum for menneskeheden at udfolde sig i samt, hvad Raworth kalder en regenerativ og distributiv økonomi. Man genkender både de 17 FN-mål og Stockholm Resilience Centers ni planetariske grænser her. Kate Raworth taler om en ny økonomi for det 21. århundrede. Hendes bog er et meget vigtigt bidrag i den sammenhæng. Markedet har fået en ubeskrivelig stor, ja, en næsten magisk og overnaturlig betydning. Markedet skal løse alle problemer, markedet skal og kan klare alt, og der eksisterer en næsten blind tiltro til markedet og dets muligheder og potentialer. Det er på én måde godt, for alt tyder på, at det faktisk er markedet, der skal være med til at løse nogle af verdens største problemer, men det skal være markeder, der fungerer under andre forudsætninger og på andre betingelser, end det sker i øjeblikket verden over. 


\section{Nogle scenarier}

Når man ser fremad, kan store ændringer forekomme vanskelige eller umulige. Men tager vi historien til hjælp, finder vi, også i den moderne historie, belæg for, at store ændringer ikke bare er mulige, men er mulige med store hastigheder. Den store acceleration efter Anden Verdenskrig er et eksempel, og den var netop karakteriseret ved meget betydelige ændringer og hastigheder. Spørg i dag et 100-årigt menneske, hvad det menneske har oplevet i sit liv. Det har fx oplevet, at der ude på landet ikke fandtes traktorer, men kun heste. Det har oplevet atombomben blive udviklet og kastet ned over mennesker. Har oplevet to verdenskrige. Ingen skal komme og sige, at der på 100 år ikke kan gennemføres gigantiske ændringer - for det kan der. Hvad kan der ikke ske i de næste 100 år? Lad os forestille os nogle scenarier for udviklingen i de nærmeste årtier, ikke scenarier i egentlig forstand, men blot nogle skitser. Scenarier er hverken utopier, idealer, visioner eller prognoser. Scenarier er beskrivelser af nogle mulige, ikke nødvendigvis skarpt adskilte, fremtider, som kan blive til virkelighed under forskellige antagelser og forudsætninger.

Den globale konkurrencesituation kan benyttes og bliver ofte brugt som argument for, at det er meget vanskeligt for virksomheder og andre at ændre strategi i retning af en mere bæredygtig udvikling. Man kan forestille sig et sådant forste scenarie, hvor verdens regeringer og private virksomheder, herunder de multinationale virksomheder, i de næste årtier i stort tal ignorerer verdensmålene, og i stedet satser på kortsigtet vækst i bruttonationalindkomst og profit, og hvor de store finansielle virksomheder gør, hvad de kan for at hjælpe med realisering af disse vækststrategier og derigennem selv opnår betydelig vækst i balancer og overskud. Man kan også forestille sig, at verdens forbrugere i det væsentlige fortsætter de indkøbs- og forbrugsmønstre, som vi kender i øjeblikket - bortset fra, at store grupper af nye forbrugere må forventes at få stedse flere økonomiske muligheder for at melde sig på markederne for forbrugsvarer. Et scenarium, der i det væsentlige går ud på en fortsættelse af de politiske og forretningsmæssige strategier, som vi ser praktiseret i dag i lande og virksomheder verden over. Kortsigtet økonomisk vækst og uændrede forbrugsvaner. Fortalerne for et sådant scenarium vil sige, at det ikke er muligt på afgørende måder at ændre disse former for forbruger-, politik- og forretningsmæssig adfærd - bl.a. med henvisning til økonomiske, konkurrencemæssige og politiske virkeligheder. Forestiller man sig dette scenarium realiseret og måske endda i nogle lande og verdensdele accelereret, så vil mange forskere nok være enige om, at det vil have meget alvorlige konsekvenser for kloden, så alvorlige, at ordet katastrofe skal tages i anvendelse. Et modificeret scenarie er et scenarium, hvor man inddrager den innovationstænkning og den teknologiske udvikling, der også 
er indeholdt i verdensmålene, dvs. opnåelse af mere forbrug og produktion med en meget mindre miljøbelastning, end vi kender i dag.

Gør man det, er vi på vej ind i et andet scenarium karakteriseret ved, at beslutningstagere verden over i de kommende år vil få mere og mere viden og indsigt, og at denne indsigt vil føre til væsentlige beslutnings- og adfærdsændringer. Man kan hævde, at det oven for nævnte scenarie i virkeligheden ikke repræsenterer en fremskrivning af tendenser, der kan iagttages i dag, og måske i særlig grad ikke, når det drejer sig om private virksomheder verden over. Det er ikke sandt, kan man sige, at virksomheder og regeringer i dag er ignoranter i forhold til de udfordringer, som verdensmålene repræsenterer, og det er ikke sandt, at der ikke finder ændringer sted vedrørende forbrugernes bevidsthed og adfærd med hensyn til indkøb og forbrug. Det er sandt, vil man sige, at regeringer og virksomheder stadig er optaget af mange kortsigtede problemstillinger, men de er også optaget af det langsigtede og af ansvaret for miljø, sociale forhold og en bæredygtig udvikling. Det er sandt, at mange forbrugere verden over foretager kortsigtede og ikke særlig bæredygtige indkøb, men det er også sandt, at der finder betydelige ændringer sted, måske ikke mindst, når man betragter de store grupper af unge generationer, der i de næste årtier bliver de dominerende forbrugergrupper. Dette er et andet scenarium, der ser oplysning, viden, bevidsthedsændringer, øget ansvarlighed - kombineret med mere og mere evidens for, at fremtidige trusler er alvor, som en vej og et forløb, der allerede kan iagttages, og som med stor sandsynlighed vil blive intensiveret i de kommende år. Man må ikke overse, at tusinder af ngo'ere, forskere og forskergrupper, tænketanke, medier, politikere, spirituelle og religiøse ledere og bevægelser, kunstnere og mange andre verden over arbejder intenst og målrettet med denne bevidstheds- og videnudvikling. Nogle forskere frygter alligevel, at dette scenarium indebærer, at de nødvendige og radikale beslutninger, der skal træffes for at undgå fremtidige katastrofer, ikke kan blive truffet hurtigt og effektivt nok på denne måde, hvorfor de vurderer, at også dette scenarium vil føre til meget alvorlige begivenheder på kloden.

En tredje mulighed er at betragte et mere frygtdrevet scenarie. Vi véd, at frygt og smerte får både mennesker og organisationer til at bevæge og forandre sig. Et tredje scenarium er derfor nærliggende, nemlig at parlamenter, regeringer, virksomheder m. fl. vil træffe mere og mere vidtrækkende og opofrende beslutninger i takt med, at de synlige beviser for fx klimaændringernes konsekvenser for vejret, oversvømmelser m.m. bliver flere og flere og mere og mere markante. Det er en forståelse og nogle sammenhænge, som vi allerede har set være 
virksomme i adskillige situationer verden over, og det må forudses, at disse mekanismer vil blive mere og mere aktive og markante i fremtiden. Det betyder, at indgrebene, forandringerne, reaktionerne m.m. netop bliver mere reaktive end proaktive, og derfor ser vi ofte en forsinket, mindre hensigtsmæssig og mindre kosteffektiv indsats, dvs. en dyrere, men ofte en virksom og voldsom indsats. Skal man tro på de kendte fremskrivninger vedrørende klima, forurening m.m., så må man betragte dette reaktive scenarie som sikkert i den forstand, at vi som minimum kan forvente en række reaktioner på den forventede udvikling overalt i verden, dvs. beslutninger og tiltag, der ikke primært er drevet af verdensmålene, men af den udvikling og de begivenheder, der næsten med sikkerhed vil ind træffe.

Den internationale konkurrencesituation kan også betragtes fra en anden vinkel, nemlig som et fænomen, der allerede har og i stigende grad og tempo i de kommende år vil drive virksomheder i en helt anden og stedse mere bæredygtig retning, ikke primært drevet af frygt, men drevet af en forestilling om, at der i den bæredygtige udvikling ligger nye muligheder for forretning, vækst og overskud, eller endnu skarpere: At den bæredygtige udvikling er fremtiden, og at de virksomheder og organisationer, der ikke forstår det, bliver fremtidens tabere; de virksomheder og organisationer, der ser det, trækker regeringer og andre med sig i bestræbelserne på at medvirke til verdensmålenes og den bæredygtige udviklings realisering.

Det er et fjerde scenarium. Mange virksomheder verden over arbejder allerede nu ud fra sådanne forestillinger. Forskellige undersøgelser, historier i medierne og en række udsagn vedrørende private virksomheder og virksomhedsledere peger i denne retning. I Danmark findes der virksomheder, der har været aktive med hensyn til verdensmålenes formulering, og som nu bevidst er optaget af målenes implementering. Og det er ikke kun de store og kendte virksomheder, der går nye veje. Tusinder af mere anonyme virksomheder gør det samme - blot uden for mediernes søgelys. Man må ikke overse, at mange erhvervsvirksomheder verden over er meget vågne, når det handler om at forstå verdens situation og udvikling, og at disse virksomheder i de kommende år vil trække verden i en ny retning. Ja, i virkeligheden skal det måske formuleres skarpere: Hvis verdensmålene skal have nogen som helst chance for bare i et vist omfang at blive implementeret inden for de næste få årtier, er en forudsætning, at mange erhvervsvirksomheder, herunder mange multinationale virksomheder verden over, bidrager i betydeligt omfang. 
Man kan forestille sig mange scenarier, både når det handler om de helt store linjer og om alle de mange lokale forløb. Man kan forestille sig alle mulige kombinationer af elementer fra de oven for omtalte skitser, herunder også, at en stor snebold, en stor bevidsthedsproces allerede er i bevægelse og vil accelerere i de kommende år med voldsom hastighed, således at verdensmålene og den etik og det natur- og menneskesyn, som verdensmålene repræsenterer, vil brede sig til stedse større dele af kloden og blive taget alvorligt af private virksomheder, forbrugere, byråd og parlamenter i et omfang, som vi i dag har svært ved at forestille os. Et sådant - femte - scenarium er muligt; og det kan også være forbundet med omfattende ændringer af de roller, som FN og andre store globale og regionale organisationer, herunder regeringsuafhængige organisationer verden over vil komme til at spille for den globale udvikling. De oven for nævnte scenarier vil i meget høj grad være påvirket og betinget af, hvad regeringer og forskellige regionale og globale organisationer beslutter i de nærmeste år. Det handler bl.a. om, hvilke rammevilkår, der tilbydes erhvervsvirksomheder, fonde, forbrugere og andre vigtige aktører.

Det er vanskeligt at foretage fremskrivninger og tydeliggøre scenarier, og i særlig grad, når det handler om globale fremskrivninger. De oven for nævnte forskellige, men ikke klart adskilte forløb repræsenterer ikke egentlige scenarier, men blot grove antydninger og spekulationer. Når vi taler om den form for ændringer, som verdensmålenes realisering eller implementering handler om, er det væsentligt at betragte alle de udviklingskurver, som repræsenterer de aspekter og dimensioner, som verdensmålene handler om, fx befolkningsudvikling, energiforbrug, $\mathrm{CO} 2-$ udledning, kvælstofkoncentration m.m. Det betyder, at vi skal betragte kurvernes øjeblikkelige niveau og udviklingsretning, men det betyder også og i særlig grad, at vi skal være optaget af, med hvilke hastigheder disse udviklingskurver ændrer sig. Det er både de konkrete udviklingsniveauer og ændringerne i udviklingshastighederne, som er vigtige for en vurdering af de langsigtede forløb og de praktiske muligheder for ændringer.

\section{Aktørerne}

Flere parters seriøse og loyale medvirken er nødvendig, hvis en mere bæredygtig global udvikling skal realiseres. Der kan peges på et antal hovedaktører:

For det første er der markedet som det sted, hvor udbud og efterspørgsel mødes. Hvor millioner af virksomheder mødes med milliarder af forbrugere. Men i praksis er der selvsagt ikke tale om én 
stor markedsplads. I praksis ser det helt anderledes ud. I praksis er der allehånde former for afgrænsninger, reguleringer, begrænsninger, aftaler, vaner, tilskud, subsidier, afgifter, skatter, lukkethed, gennemsigtighed m.m. De omkostninger, der indgår i virksomhedernes kalkuler og priser, er sjældent de reelle ofre eller omkostninger, der er forbundet med at producere eller frembringe det pågældende produkt eller ydelse. Ofte er der ofre og konsekvenser for naturen, mennesker og dyr, der ikke medregnes, men som alligevel til syvende og sidst spiller en stor rolle i det store natur- og samfundsregnskab. Ofte vil der være skatter, afgifter, told og andet, der medvirker til at skævvride den prisdannelse, der finder sted. Der kan være allehånde slags aftaler imellem udbyderne, virksomhederne, der fastholder priserne på det pågældende marked på et unødvendigt højt niveau, og der kan også på købersiden være forhold, der fremtvinger eller muliggør en skævvridning af markedet. Virksomhedernes størrelse spiller i den sammenhæng en stor rolle. Er der på markedet et stort antal stort set lige store virksomheder, eller er der på markedet én virksomhed eller blot én dominerende virksomhed og et antal mindre virksomheder eller hvordan ser udbydersiden ud? Og tilsvarende: Hvordan ser markedet for indkøb ud? Der vil her fx være stor forskel med hensyn til, om det handler om erhvervsmæssigt og såkaldt professionelt indkøb, eller om det handler om såkaldt almindelige private forbrugere. Begrebet, markedet, for ikke at tale om begrebet, verdensmarkedet, er derfor et ekstremt sammensat begreb. Alligevel taler vi ofte om det, som om det er meget enkelt og gennemskueligt. Det er det ikke. Men det er ikke desto mindre her, verdens udvikling med hensyn til bæredygtighed eller ikkebæredygtighed i stort omfang bestemmes. Men ikke udelukkende.

For det andet er parlamenter, regeringer, diktatorer, regionsråd, byråd m.m. verden over også medbestemmende - og på visse områder i meget høj og afgørende grad. Skal udviklingen i verden på bæredygtighedsområdet ændres i de kommende år, kræves der politiske nationale og internationale ændringer. Det er en forudsætning for ændringer på bæredygtighedsområdet, at de nævnte politiske forsamlinger og myndigheder ændrer politik, dvs. træffer andre beslutninger, der fører til, at det, der tidligere er omtalt som virksomhedernes strategiske råde- eller handlingsrum, ændres. Det er virksomhedernes strategiske og operationelle råderum, der til syvende og sidst er afgørende for, hvad der udbydes på markederne og til hvilke priser, og sådan som den nuværende lovgivning og de nuværende globale aftalesystemer er indrettet, er det helt sikkert, at ikkebæredygtig produktion vil få lov til at dominere den fremtidige produktion og det fremtidige udbud. Det er urealistisk at forestille sig, at de private virksomheder af egen drift og inden for de eksisterende markeds- og skatte- og afgiftsstrukturer skal ændre produktion og udbud i et sådant 
omfang, at den globale bæredygtighedsudvikling afgørende vil blive ændret. Set i relation til de 17 bæredygtighedsmål gælder det derfor også, at det er en forudsætning for disse måls nødvendige implementering, at parlamenter og regeringer medvirker til at ændre de rammer og vilkår, som aktivitet og produktion i private virksomheder verden over foregår under.

For det tredje: Civilsamfundsorganisationer verden over, hvoraf der er mange millioner, skal medvirke på flere måder. Disse organisationer skal medvirke med information, videnformidling, agitation, oplysning m.m. verden over. En global bæredygtig udvikling er i meget høj grad et spørgsmål om bevidsthedsudvikling hos verdens borgere, og de mange millioner civilsamfundsorganisationer spiller en uhyre stor rolle her. På samme måde spiller uddannelsesinstitutionerne en afgørende rolle; det handler om grundskoler, fagskoler af mange slags, universiteter og andre typer af uddannelsesinstitutioner. I Danmark eksemplificeret med Det Kongelige Danske Kunstakademis Skoler for Arkitektur, Design og Konservering Arkitektskolen.

Og endelig for det fjerde må der peges på de finansielle institutioner verden over. Både private og statsejede banker og finansieringsinstitutioner og de forskellige internationale institutioner som fx Verdensbanken kommer til at spille en afgørende rolle for bæredygtighedsudviklingen.

Betragter vi specifikt de 17 verdensmål, er der foretaget mange beregninger, der viser, at der er behov for investeringer til mange trillioner kroner, såfremt verdensmålene skal implementeres.

Som i alle sådanne komplicerede situationer kan man ikke sige, at det ene er vigtigere end det andet; alle elementer er nødvendige og er hinandens forudsætninger. Generelt betragtet er det på den ene side åbenbart, at verden står over for en meget - for ikke at sige en ufattelig - kompliceret og konfliktfyldt proces på bæredygtighedsområdet i de kommende årtier. På den anden side kan det umiddelbart og let konstateres, at alle de nævnte aktører og institutioner er i fuld gang med denne udvikling. Der er en udvikling i gang overalt i verden, og det er ikke svært at forestille sig et tipping point, ud fra hvilket bæredygtighedsudviklingen accelererer. Skal man være realistisk, må det formentlig siges, at et sådant tipping point skal nås inden for en ganske kort årrække, såfremt meget alvorlige begivenheder skal undgås. Betragtes de sidste ét eller to årtiers globale bæredygtighedsudvikling, er det meget let at mobilisere en betydelig optimisme ud fra den hastighed, hvormed interessen for, engagementet i og også de konkrete aftaler og initiativer på bæredygtighedsområdet har fundet sted. Tænk blot på de 17 verdensmål fra 2015 og Paris-aftalen 
fra 2016; tænk på millioner af civilsamfundsinitiativer verden over; tænk på bøger, forskning og megen anden formidling, andre politiske initiativer, fx det danske tværpolitiske netværk i Folketinget m.m. Tænk på, hvor meget eller hvor lidt bæredygtighed fyldte i verden for 10 år siden og sammenhold det med udbredelsen, engagementet og intensiteten i dag.

\section{E. Den næste 15-års plan}

Femten år er en meget kort periode. Det er imidlertid åbenbart, at det er muligt med en FNresolutionen om verdensmålene og med en omfattende og global oplysningsvirksomhed, politisk aktivitet og meget andet at igangsætte en global bevægelse - formentlig af hidtil uset omfang og styrke. Det er, hvad der er sket i verden i de sidste få år, siden verdensmålene blev vedtaget i september 2015. I formentlig alle lande, med forskellig styrke og omfang, er der initiativer vedrørende verdensmålene.

Erhvervsorganisationer, erhvervsvirksomheder, uddannelsesinstitutioner, fagforeninger, universiteter, civilsamfundsorganisationer, oplysningsforbund, politiske partier, parlamenter, byog regionsråd - overalt er der opmærksomhed, forslag, initiativer, spørgsmål, debatter,

Snart er de femten år gået - og hvad så? Efter al sandsynlighed vil verden være kommet positivt længere på alle 17 måldimensioner i år 2030. Med al den opmærksomhed, der allerede nu kan iagttages, og med den alvor, der allerede nu karakteriserer situationen i verden, når man betragter de 17 mål-dimensioner, må det antages, at intensiteten med hensyn til indsatsen for verdensmålene verden over vil intensiveres i de kommende år og tage voldsom fart i de sidste år frem $\bmod 2030$.

Imidlertid kan der også let i perioden frem mod 2030 ske kontraproduktive begivenheder, også jfr. de før omtalte risikovurderinger fra fx Verdensbanken og WEF. Det betyder, at der i den omhandlede periode også kan ske begivenheder, der voldsomt modvirker opnåelsen eller indfrielsen af verdensmålene. Og man skal måske ikke sige 'kan ske', men vil ske? Det er altså en meget usikker periode, vi står over for med verdensmålene, men vi tillader os den vurdering og antagelse, at der vil være sket markante, positive og verdensomspændende fremskridt, inden 2030. 
Lige så sikkert er det, at der i 2030 så at sige resterer en række problemer og udfordringer, og det betyder, at verden i årene frem mod 2030 også skal arbejde med en ny plan, nye mål for verdens udvikling, og her vil der med sikkerhed i årene frem mod 2030 være indhøstet så mange erfaringer med de nuværende 17 verdensmål, at det vil være nemmere at komme videre, formuleringsmæssigt, forhandlingsmæssigt, kommunikationsmæssigt, ledelsesmæssigt mm. fra 2030, når man gør nytte af alle de erfaringer, der er indhøstet i perioden 2015-2030.

\section{Litteratur}

Brundtland, Gro Harlem \& World Commission on Environment and Development: Our Common Future. Report of the World Commission on Environment and Development. Oxford University. Oxford 1977.

Capra, F. \& Pier L. Louisi: Individ. System. Helhed. Mindspace. København 2016.

Crutzen, Paul: Anthropocene man. Nature, vol. 467, 2010.

Den sjette masseuddøen: Jordens liv forsvinder lidt efter lidt. Videnskab.dk, 2018.

Harari, Yuval Noah: Sapiens. En kort historie om menneskeheden. Lindhardt \& Ringhof. København 2015. (Udgivet på israelsk og engelsk i 2011).

Hildebrandt, Steen: Vækst og bæredygtighed. Forlaget Libris. 2. udgave. København 2015.

Hildebrandt, Steen (red.): Bæredygtig global udvikling. Om FN’s 17 verdensmål set fra et dansk perspektiv. Jurist- og Økonomforbundets Forlag. København 2016.

Hildebrandt, Steen: Astronautens blik. Jensen \& Dahlgaard. København. 2016.

Rockström, Johan og Mattias Klum: Big World Small Planet. Bokförlaget Max Ström. Stockholm. 2015.

Rockström, Johan og Mattias Klum: The Human Quest. Prospering within Planetary Boundaries. Bokförlaget Langenskjöld. Stockholm 2012.

Sachs, Jeffrey D.: The Age of Sustainable Development. Columbia University Press. 2015. https://doi.org/10.7312/sach 17314 